\title{
Rearanżacja przestrzeni osiedla przez lokatorów społecznego budownictwa czynszowego
}

\section{Rearrangement of a housing estate by the tenants of social rental construction}

\begin{abstract}
Streszczenie
Celem pracy jest ustalenie czy, a jeśli tak to w jaki sposób, najemcy społecznego budownictwa czynszowego, dopasowują przestrzeń zamieszkania do swoich potrzeb oraz czy restrykcyjny regulamin porządku domowego ogranicza jej symboliczną identyfikację. Przedmiotem badań jest dwubudynkowy zespół mieszkaniowy Szczecińskiego Towarzystwa Budownictwa Społecznego (STBS), a w nim stan zagospodarowania widocznych przestrzeni rekreacyjnych (balkonów, loggi i przedogródków) po 10 latach od zasiedlenia. Przeprowadzone badania wskazują, że budownictwo czynszowe nie jest pozbawione praktyk charakterystycznych dla prawa własności. W rekreacyjnej przestrzeni mieszkaniowej postępuje proces zmian, które manifestują prywatność i strzeżenie granic, potrzebę izolacji i osobności, sprzyjają prezentacji widocznych elementów lokali, manifestują terytorialność, budują tożsamość z miejscem oraz personalizują przestrzeń. Obserwowana lokatorska rearanżacja przestrzeni mieści się w granicach określonych zasadami regulaminu porządku domowego.
\end{abstract}

\begin{abstract}
The purpose of the paper is to determine whether, and if so how, the tenants of social rental construction adjust the living space to their needs and whether restrictive housekeeping regulations restrict its symbolic identification. The subject of the analysis is a two-building housing complex of the Szczecin Society of Social Housing (STBS), and in it the state of development of visible recreational spaces (balconies, loggias and frontyards) after 10 years from settlement. The research carried out indicates that the rental construction is not devoid of practices characteristic of property rights. In the recreational housing area there is a process of change that manifests privacy and border guarding, the need for isolation and separation, favors the presentation of visible elements of premises, manifest territoriality, build identity with the place and personalize space. The observed space rearrangement is within the limits defined by the rules of the housekeeping regulations.
\end{abstract}

Słowa kluczowe: społeczne czynszowe budownictwo mieszkaniowe, przestrzeń osiedla, regulamin porządku domowego, strefa rekreacji, zadomowienie, personalizacja, terytorializm

Keywords: social rent housing, housing estate, housekeeping regulations, recreation zone, domination, personalization, territoriality

\section{Wstęp}

Najbardziej typową formą miejskiego mieszkalnictwa jest blok. Jego zasiedlenie rozpoczyna zindywidualizowaną rearanżację przestrzeni zamieszkania. Przestrzeń nabiera nowych form i znaczeń, manifestowanych w przeróżny sposób. Początkowo identyczne balkony i loggie stają się wizytówką mieszkańców a jednocześnie ekotonem, rozdzielającym prywatną, izolowaną przestrzeń mieszkania od otoczenia. $W$ rezultacie schematyczny, zunifikowany blok, z czasem staje się różnorodną, spersonalizowaną przestrzenią zamieszkania.

Forma i skala rearanżacji przestrzeni ma związek z tytułem władania nieruchomością, czasem zamieszkiwania, statusem ekonomicznym mieszkańców, ich wykształceniem i wyznawanymi przez nich wartościami. Regulatorem zachowań mieszkańców jest regulamin porządku

\section{Introduction}

The most typical form of urban housing is a block of flats. Its settling begins with an individualized rearrangement of the living space. Space takes on new forms and meanings manifested in various ways. Initially identical balconies and loggias become the showcase of the inhabitants and, at the same time, an ecotone, separating the private, isolated space of the flat from the surroundings. As a result, a schematic, unified block, over time, becomes a diverse, personalized living space.

The form and scale of rearranging space is related to the title of property management, residence time, economic status of residents, their education and values they profess. The rules of the residents' be-

* Dr hab. inż. Anna Kiepas-Kokot, Katedra Ekologii Ochrony i Kształtowania Środowiska, Wydział Kształtowania Środowiska i Rolnictwa, Zachodniopomorski Uniwersytet Technologiczny w Szczecinie / Department of Ecology, Environmental Protection and Management, West Pomeranian University of Technology in Szczecin, e-mail: Anna.Kiepas-Kokot@zut.edu.pl, ORCID: 0000-0002-0020-0083 ** Inż. Angelika Żądłowska, absolwentka studiów inżynierskich kierunek: Gospodarka przestrzenna / graduate of engineering studies in the field of: Land management, ORCID: 0000-0001-8441-3053 
domowego. Działania mieszkańców nie pozostają bez związku z jakością najbliższego otoczenia, zachęcającego do integracji lub wymuszającego izolację

2. Specyfika budownictwa społecznego

Społeczne budownictwo czynszowe, funkcjonujące $w$ formie towarzystw budownictwa społecznego (TBS), jest dedykowane zaspakajaniu potrzeb mieszkaniowych osób dla których nie jest dostępny zakup mieszkania na własność lub najem rynkowy. Istotą działania TBS jest budowanie domow mieszalny h i ich elsploataja na zasadach najmu.' Prawo do najmu lokalu poprzedza weryfikacja sytuacji mieszkaniowej osób zgłoszonych do wspólnego zo.2 Ścína oraz dochod zospodarstwa domowedo jednorodności społeczno-ekonomicznej mieszkańców, często określanych jako „średniozamożni” [1]

Budownictwu społecznemu, działającemu na zasadzie non profit, stawiane sa wysokie wymagania zasadzie i ograniczenia kosztów eksploatacii [2] Stawki czynszu sa ustalane w takiej wysokości, aby suma czynszów pozwalała na pokrycie kosztów eksploatacii i remontów oraz spłate zwiazanych z budowa zobowiazań TBS. Budownictwo społeczne charakteryzuje wysoka ność i ciagłość wynajmu [1]. Najemcy nie traktuja TBS jako drogi do osiagnięcia mieszkania, a raczej jako cel [3]. W efekcie mimo lokatorskiego posiadania mieszkania, powstaje trwały zwiazek wiekszości mieszkańców z przestrzenia, co tworzy korzystne warunki do jej zadamawiania i podporządkowywania własnym potrzebom.

\section{Charakterystyka osiedla "Brzozowy zakątek"}

Projekt wielorodzinnego osiedla mieszkaniowego „Brzo zowy zakątek" został wyłoniony w drodze konkursu architektonicznego ogloszonego przez STBS w 2006 który wygrała Pracownia Projektowa Portal ze Szczecina (City-Architekci, właściciel arch. Maciej Zombirt). Po dwuletnim procesie inwestycyjnym (w 2010 r.) oddan do użytku dwa 4-kondygnacyjne, niepodpiwniczone budynki mieszkalne, zlokalizowane przy zbiegu ulic Jana Kazimierza i Gontyny w Szczecinie (il. 1). Budynki zlokalizowano w centralnej częsci miasta (Dzielnica Śródmieście, Osiedle Dzetowo-Grabowo), z dużą dostępnościa do zbiorowej komunikacji publicznej, usług publicznych i rynkowych. W budynkach znajduje się 168 lokali miesz kalnych, o tącznej powierzchni uzytkowej 8 749,23 m²

Osiedle charakteryzuje prosty, przejrzysty układ urbanistyczny z nieskomplikowaną organizacją ruchu pieszego, z jednym głównym ciągiem przechodzącym przez od którego odchodza chodniki prowadzace do wejść do budynków (il.2). Ustawienie budynków naturalne wyniesienie terenu oraz mur oporowy wokół osiedla stwarza wrażenie przestrzeni niedostepne dla "niemieszkańców" (bliskie osiedlom grodzonym) i skutecznie izoluje dziedziniec od hałasu drogowego W środkowej części dziedzińca znajduje się ogrodzony plac zabaw, którego usytuowanie umożliwia sprawowa nie kontroli rodzicielskiej oraz zachowań innych osób. Dobre oświetlenie osiedla sprzyja poczuciu bezpieczeństwa i zwiększa pole obserwacji. havior are the rules of the house order. The actions of the residents are not unrelated to the quality of the immediate environmetsnt, encouraging integration or forcing isolation.

2. The specificity of social housing

Social housing construction, functioning in the form of social housing associations (TBS), is dedicated to satisfying the housing needs of people for whom it is not possible to buy a flat or lease a market. The it sence of TBS's operation is building residential houses and their exploitation on a lease basis'. The right to lease the prenises is preceded by a verifetigh the housing position of the persons designad for the housing position of the persons designated for Strictly defind rus Striclly defined rules for the selection of tenants lead to a socio economic homogen (11. of residents, ofte referred to as "middle-class" [1].

Social construction, acting on a non-profit basis, faces high technical requirements and reduced operating costs [2]. Rental rates are set in such a way tha the sum of rent allows to cover the costs of operatio and repairs as well as repayment of TBS liabilities related to construction

Social construction is characterized by high reliability and continuity of renting [1]. Tenants do not treat TBS as a way to acquire a flat, but rather as an objective [3]. As a result, despite the tenant's ownership of the flat, a lasting relationship between the majority of the inhabitants and space is created, which creates favorable conditions for her to settle and subordinate to her own needs.

corner"

acteristics of "Brzozowy zakątek" / "Birch

The project for a multi-family housing estate named Brzozowy zakatek" was selected during an architectura competition announced by STBS in 2006 , which was won by Pracownia Projektowa Portal from Szczecin (City-A chitekci, owner of architect Macie Zombirt). After a two-year investment process (in 2010) two 4 storey, cellfree residential builings, located

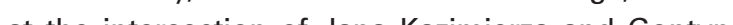
Streets in Szczecin (it. 1). The buldings are locied in the cental part of the city (district: Ś estate: Diel part of the city (distict. Srodmiescie, collective public trabovo, wh a wide access to corive mercial services. In the buildings there are 168 resi$\mathrm{m}^{2}$ inhabited by 411 residents

The estate is characterized by a simple, transparen urban layout with an uncomplicated organization of pedestrian traffic, with one main passage passing through the courtyard from which they leave walkways leading to entrances to buildings (il.2). The location of the buildingsThe natural elevation of the terrain and the retaining wall around the estate cre-

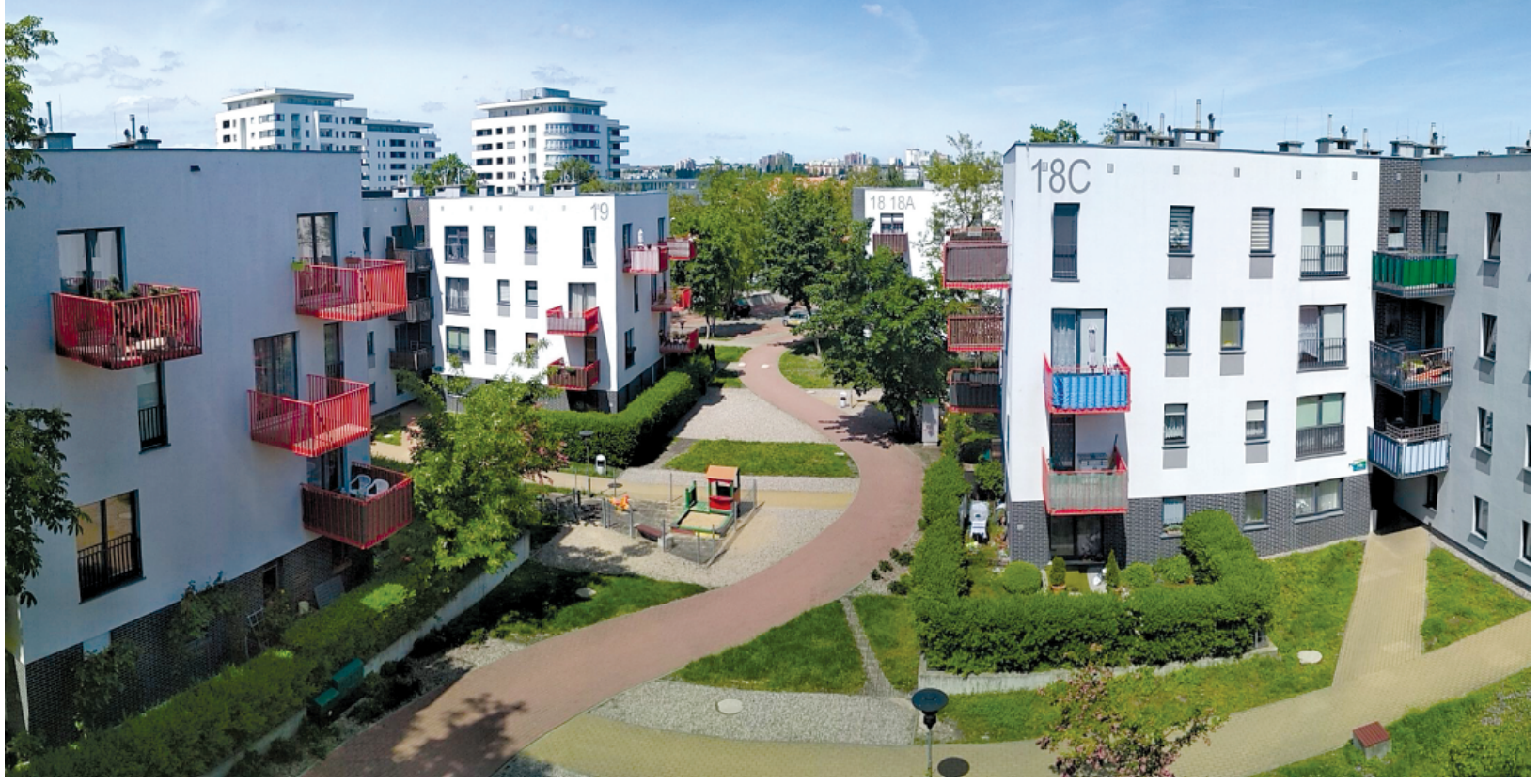

il. 1. Widok na budynek osiedla „Brzozowy zakatek” od ul. Jana Kazimierza (fot. A. Żądłowska) / A view of the „Brzozowy zakątek” housing esta-
te from the Jana Kazimierza street (fot. A. Ządlowska)

stotnym zasobem tego niewielkiego osiedla jest zieleń, w skład której wchodzi 122 drzewa, z czego blisko połowe (54) stanowia brzozy Osiedle jest korzystnie usytuowane względem dwóch parków miejskich (Park Żeromskiego oraz Park im. Stanisława Nadratowskiego zlokalizowanych w dystansie 150-200 m.

4. Regulamin porządku domowego

Regulamin porządku domowego jest zbiorem zasad porządkujących korzystanie z lokali i otaczającej przestrze przez wielu użytkowników. Jego przestrzeganie umożliwia zachowanie czystości i porządku oraz sprzyja ograniczaniu uciązlíwości wynikających z rożnych aktywnosci mieszkańców i ich gości. Najemca jest zobowiązany przestrzegac zasad regulaminu (ilub umowy najmu) al także reguł wynikających z przepisów prawa ogólnego. Regulamin osiedla "Brzozowy zakątek" ${ }^{\text {" }}$ zobowiązuje najemców do natychmiastowego informowania zarządcy o jego naruszeniu, co tworzy warunki wewnętrznej kontroli reguł współzycia społecznego przez mieszkańców. Rażące lub uporczywe naruszenia co najmniej jedne go z zapisow regulaminu może stanowić podstawę do wypowiedzenia umowy najmu, jak rownież podstaw do wytoczenia przez innych mieszkańców powództwa o roźzizizanie przez sad stosunku prawnego i nakazanie

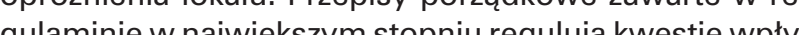
wajace na bezpieczeństwo ośb i mienia m.in poprzez postepowanie z substanciami i przedmiotami, gtównie odpadami, zakazuiac ich przechowywania i wystawiania $w$ miejscach do tego nieprzeznaczonych. Uregulowanie kwestie gospodarowania odpadami, zwłaszcza zbednymi sprzetami wielkogabarytowymi, ma ponadto znaczenie estetyczne i wizerunkowe dla osiedla. Wprowadzony na terenie osiedla regulaminowy zakaz rozpalania ognisk i używania grillów, eliminuje możliwość biesiadowania i ogranicza zagrożenie pożarowe. Względy bezpieczeństwa zdecydowały również o ustanowionym zakazi umieszczania skrzynek $i$ donic na kwiaty na parapetach okiennych, elewacjach budynków $i w$ innych miejscach ates an impression of a space that is inaccessible to "non-dwellers" (close to gated communities) and efectively isolates the courtyard from traffic noise. IN In the central part of the courtyard there is a fenced playground whose location allows you to exercise parental control and other people's behavior. Good lighting of the estate favors a sense of security and increases the field of observation.

An important resource of this small estate is greenery, consisting of 122 trees, of which nearly half (54) are birches. The estate is favourably located between two city parks (Żeromski Park and Stanisław Nadratows Park), located within the distance of $150-200 \mathrm{~m}$.

\section{Housekeeping regulations}

Housekeeping regulations are a set of rules organizing the use of premises and the surrounding space by many users. Its observation makes it possible to preserve cleanliness and order, and helps reduce the nuisances caused by various activities of residents and their guests. The tenant is obliged to comply rules of the regulations (and / or lease agreements) but also rules resulting from the provisions of general law.

The regulations of „Brzozowy zakątek" oblige tenants to immediately inform the manager about its violation, which creates conditions for internal control of the rules of social coexistence by the residents. Glaring or persistent violations of at least one of the provisions of the regitations of at least one of the provisions of the regulations may constitute grounds for termination of the lease agreement, as well as to basis for bringing a lawsuit by other residents to dering to terminate the legal relationship and or regulations included in the regulations to the greatest extent regulate the issues affecting the safety of persons and property, including through handling of 
mogących powodować zagrożenie dla mieszkańców pościeli $i$ odzieży oraz suszenia bielizny $w$ oknach $i$ n parapetach oraz $w$ pomieszczeniach wspólnego użytk $i$ na terenach przyległych do budynków, poza wyznaczonymi pomieszczeniami pralni lub suszarni. Ograniczeniu uciążliwości wynikających $z$ różnych aktywności użytkowników dedykowano zakaz gry $w$ piłkę $w$ obrębie budynków $i$ na terenach przyległych do budynków oraz zabawy, uprawiania sportów (jazda na rowerach, rolkach $i$ deskorolkach itp.) $i$ rekreacji poza terenami do tego wy znaczonymi. Bezwzględnie zakazano spożywania wszelkich napojow alkoholowych zarówno $w$ obrębie częsci wspónych budynk

W aspekcie ksztattowania przestrzeni osiedla za najistotniejszy można uznać regulaminowy zakaz (bez zgody STBS) wykonywania ogrodzeń, montowania pergoli, krat, siatek na pnącza oraz ustawiania na terenach przyległych do budynków elementów małej architektury i urzadzeń do przywiazywania psów czy parkowania rowerów. Zakazem zostało też objete instalowanie urzadzeń nadawczych odbiorczych anten radiowych lub telewizyjnych w obrebie budynków $i$ terenu przylegtego (nie wyłączając okien, balkonów $i$ tarasów, elewaci budynków, przedogródków itp.). Zabroniono również malowania ścian zewnętrznych $i$ wewnetrznych cześci wspólnej budynku oraz wieszania na nich jakichkolwiek

il. 2. Widok na dziedziniec osiedla „Brzozowy zakatek" (fot. A. Żadowsowka) /
View of the courtyard of the „Brzozowy zakatetek" estate (fot. A. Ządtowska)

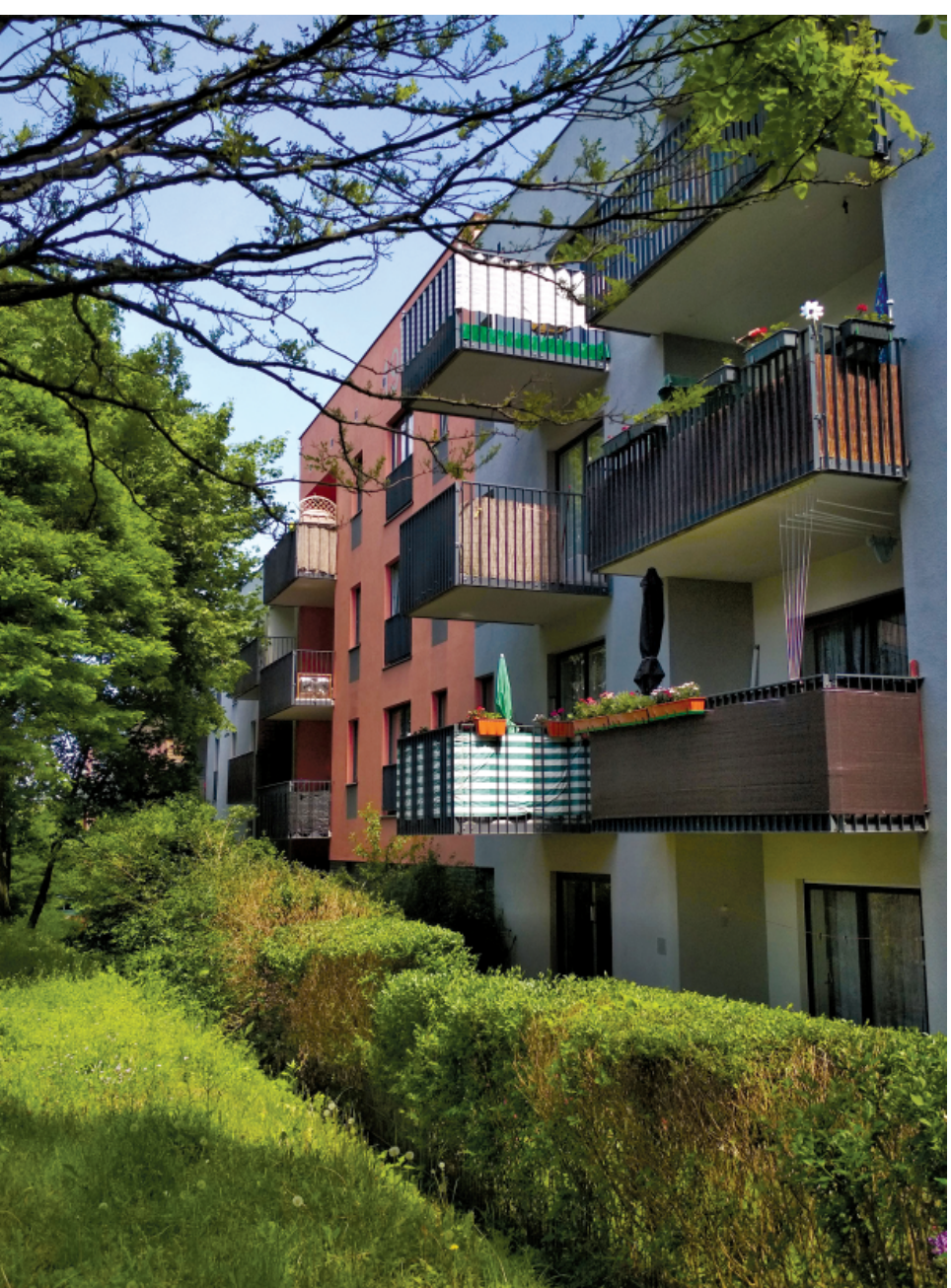

substances and objects, mainly waste, prohibiting Regulation of was display in non-designated spaces. with unnecessary large-size equipment, also has aesthetic and image significance for the housing estate. Introduced within the estate by the regulations prohibiting the lighting of fires and the use of grills, eliminates the possibility of feasting and reduces the risk of fire Security reasons have also decided about the ban onplacing boxes and flower pots on window sills, building facades and on other phos winmay pos, a threat to reses and on other places tha mav pose a the tro residents or threaten property the at maintaining the aestelic order, e.viventalion of beding and dow sils as well as in con dow sils as well as in comm areas and on areas adjacent to bulldings, ou a laundry or drying room. Limitation of nuisances re sulting from various activities of users was dedicated to banning ball games within buildings and areas adjacent to buildings, and playing, sports (riding on bicycles, rolls and skateboards, etc.) and recreatio outside the designated areas. It is strictly forbidden to consume any alcoholic drinks both within the common parts of the buildings and in the areas adjacent to the buildings.

In terms of shaping the housing estate's territory, the most significant ban is the statutory ban on (doing so without the consent of STBS) onmaking fences, mounting pergolas, grates, casing nets, and setting up small architectural elements and equipment for tying dogs or parking bicycles in areas adjacent to buildings. The ban also covered installation of transmitting, receiving devices, radio or television antennas within buildings and adjacent areas (including windows, balconies and terraces, elevations of buildings, przedogródków, etc.). It was also forbidden to ings, przedogrodkow, etc.). It was also forbidden to building and to hang any signs, pictures and advertiser. they they do neestate to the needs and expectations of indvidual tenants. However, these are not absolite prohibitions and sent of STBS.

5. Dweller's rearrangement of the housing estate The activity of the tenants of "Brzozowy zakatek" encompassed the recreation zone of the housing estate and in particular the recreation housing zone, which includes balconies and loggias (assigned to each residential premises) and pregregens (assigned to premises located on the ground floor). In the frontyards, a user realizes the need for contact with nature, and at the same time is somewhat forced to relate to the community that uses the public space adjacent to [4]. The frontyards (in the amount of 35) constitute tabliczek, obrazków i reklam. Zakazy te istotnie ogranilowej przestrzeni do potrzeb i oczekiwan poszczegónych lokatorów. Nie są to jednak zakazy bezwzględn a odstępstwo od nich jest warunkowane uzyskaniem zgody STBS.

\section{Lokatorska rearanżacja przestrzeni osiedla}

Aktywność lokatorów „Brzozowego zakątka” objęła strefę rekreacyjną osiedla a w szczególności rekreacyjn strefe mieszkaniowa, w skład której wchodzą balkony loggie (przypisane każdemu lokalowi mieszkalnemu) oraz przedogródki (przypisane do lokali znajdujących się na parterze). W przedogródkach użytkownik realizuje potrzebè konta tu zrzyroda, a jednocześnie jest sasiaduja z nim przestrzé publiczna [4]. Przedogródki ( $w$ liczbie 35) stanowi znaczacy udziat w przestrzeni rekreacii osiedla Sa zgrupowane na trzech obszarach: od strony dziedzińca (13). ul. Jana Kazimierza (12) i ul. Gontyny (10), bedacej jednocześnie dojazdem do rozlegtego osiedlowego parkingu. Mieszkańcy lokali znajdujacych sie na parterze moga na teren przedogródków zejść z mieszkania. W koncepcji osiedla zakładano, ż bẹda one stanowity element strefy publicznej osiedla. Faktycznie jednak przedogródki zostały ogrodzone i sa dostepne wyłącznie dla lokatorów przyległych mieszkań. W ten sposób uksztaltowano przestrzeń półprywatną, na styku lokalu mieszkalnego i przestrzeni publicznej osiedla. Lokatorzy zagospodarowali praktycznie wszystkie udostępnione im przedogródki (z wyjątkiem jednego). Wcześniej zunifikowane ogrodzenia przedogrodkow zostały w częsci (23\%) przesłonięte płotam kratkowymi (6 obiektów), matą osłonową (1) i płotem sztachetowym (1). Na jednym z ogrodzeń (przy głównej częsci parkingu osiedla, od strony ul. Gontyny) w niezidentyfikowanym celu umieszono ponadto drut kolczasty. W niektórych przedogródkach umieszczono paraso przeciwsłoneczny (2) i pawilon ogrodowy (1). Zastosowane przez lokatorow osłony są nieobecne w przedogrodkach od strony dziedzińca, sporadycznie występują od strony ul. Jana Kazimierza (20\%) i charakteryzuja wszystkie przedogrodki widoczne od strony parking (ul. Gontyny). Poza ostonami technicznymi do izolaci estetyzacji przedogrodków powszechnie wykorzystano pnącza, krzewy, w tym najczęsciej zywotniki w układzie pre tym czessza im oyczeje mniej przyjazne bardzie uciazliwe. Uciażliwość otoczenia od strony parkingu nie jest powodowana wytacznie ruchem pojazdów ale jest również wynikiem odbywajacych sie tam spotkań jie mieszkańców". Funkcja spoteczna przedogródków jest wiéc silnie determinowana jakócia pasiednie przestrzeni publicznej. Im ta jest mniej satysfakcionujaca tym obcowanie lokatorów z przyroda staje się bardziej wyizolowane, mniej społeczne.

Zadomawianie prywatnej przestrzeni $[5]^{6}$ jeszcze wyraźniej niż w przypadku przedogródków, widać na przykładzie loggi i balkonów. Ich bezpośrednie powiazanie z przestrzenią mieszkania, czyni je strefą liminalną [6] Ich duża liczba (82 balkony, 51 loggi) stwarza korzystne a significant share in the housing estate's recreation space. They are grouped in three areas: facing the courtyard (13), at Jana Kazimierza street (12) and Gontyny street (10), which is also an access to a wide estate's car park. The residents of the premises located on the ground floor can go down to the predugout area from the flat. The concept of the estate assumed that they would be a part of the public zone of the housing estate. In fact, however, the frontyards have been fenced and are available only for tenants of adjacent flats. In this way, the semi-private space was formed, at the interface of the residential and we purlic space of the housing estate. The residents ed all frontyards provided to . (1) On of of the fences (near the man part of the esate's parking lot, facing at Ge main pant of the eswire was a ot, facing at Gontyny street), barbed wome frolso placed for an unidentified purpose. In vilion (1) wars, a sun umbrella (2) and a garden pa(1) were placed. Shields used by the tenants and and sporadically occur on the side facing at Jan Kazimicrza street (20\%) and characterize all fronyards visible at the side facing the car park (Gontyny trect). In addition to technical shields for isolation and aesthetization of pre-dug trees, vines and shrubs were commonly used, including the hedgerow in the hedge arrangement. The isolation of private recreational space is the more frequent the less friendly and more troublesome surroundings. The nuisance of the environment on the side facing the car park is not only caused by the movement of vehicles but it is also the result of meetings held by "non-residents". The social function of frontyards is therefore strongly determined by the quality of the neighboring public space. The less satisfying it is, the more isolated and ess social the resident's being with nature becomes. The taming of private space $[5]^{6}$ is visible even more in loggias and balconies than in the case of frontyards. Their direct connection with the living space Thes them a liminal zone $[6]^{7}$. Their large number 82 balconies, 51 loggias) creates favorable conditions for exposing the individuality of tenants, resulting in a variety of arranged space. The barriers of balconies and loggias in residential buildings were made of steel. They are fully openwork barriers, varied only by the colors. Currently, on the vast majority of them (95\% balconies and all loggias), the tenants have placed covers of different colors and heights in relation to the barriers, made of various materials. The most widely used were cover mats (over $70 \%$ of balconies and loggias), much less frequently (in several cases) rail and shield fences. ,Occasionally umbrellas are placed on balconies and loggias. Loggias facing the side of the car park are also characterized 
nych najemców, co czwarty wskazał, że był świadkiem aktów wandalizmu i wykroczen takich jak: Wlamania do samochodów na parkingu osiedla, kradzież elementow ich wyposazenia lub częsci, oblanie farbą samochodu, niszczenie zamka do wiat smietnikowych, czy wyrzucanie z pobliskiego budynku z lokalami socjalnym ostrych przedmiotów i żywności. Co piąty ankietowany wskazal, że by swiadkiem zażywania w publicznej przestrzeni rekreacyjnej osiedla używek, w tym alkoholu. A $60 \%$ ankietowanych deklarowało, że przyjmuje aktywną postawe wobec naruszeń przepisów porządkowych w przestrzeni publicznej osiedla, osobiście upominając osobe naruszającą obowiązujące reguły (40\% respondentów), zgłaszając naruszenie służbom porządkowym (15\%) lub zarządcy $(5 \%)$. Bezpośrednie upomnienia lonatorzy adresuja przede wszystkm do waścicieli psow granicami osiedla, co nierzadko prowadzi do sprzeczek i kłótni. Jako rozwiazani ta po prowu niktórzy z respondentów postulowali ograniczenie dostepności tereńw publicznych osiedla dla miemieszkańć́w" przez jego ogrodzenie. Deklarowane przez ankietowany powszeche sprawowanie kontroli nad zachowniam osób korzystajacych z przestrzeni publicznej osied wskazuje na wysoki poziom identyfikacji mieszkańcóo z miejscem zamieszkania, czemu nie przeszkadza brak z miejscem zamieszkania, czemu nie przeszkadza brak jacy na obserwowane działania niezgodne z przepisam porządkowymi uzasadniali to m.in. chęcią zachowania neutralności w sytuacji trudnej albo niską szkodliwościa społeczną tych czynów. W ocenie respondentów osiedle jest uznawane za bezpieczne i bardzo bezpieczne $(77,5 \%$ respondentów). Lokatorzy wskazali jako obszar zagroże nia kryty osiedlowy parking i sąsiedztwo terenu osiedla z budynkiem z lokalami socjalnymi. W miejscach tych lokatory wskazywall na niszczenie i okradanie pojazdów, niebezpieczeństwo kolizji z pojazdami oraz uciąż liwe zachowania lokatorów mieszkan socjalnych t.j. wy rzucanie z okien niebezpiecznych, ostrych przedmiotów żywności oraz zalatwianie potrzeb fizjologicznych. Ni bez powodu więc lokatorzy właśnie od strony parking i budynku z lokalami socjalnymi częściej izolują swoj prywatna przestrzeń rekreacij od otoczenia.

\section{Podsumowani}

Lokatorzy TBS funkcjonuja w systemie silnych ograniczen wynikających z zasad regulaminu porządku domo wypowiodzenia umowy naimu. Regulaminowta ogranczenie swobody w rearaniacii przestrzeni nie wyeliminowato praktyk jej personalizacii. 8 Dziatania najemców mieszcza sie zasadniczo w regutach dopuszczalnych zmian określonych w regulaminie. To co dopuszczaln i potrzebne najemcom, jak izolacja prywatnej przestrze ni rekreacyinej, jest powszechnie stosowane. Terytrializm $^{9}$ jest bardziej wyrazisty w sasiedztwie nieprzyjazne przestrzeni publicznej, penetrowanej przez niemiesz kańców". Najemcy utożsamiają się z miejscem zamieszkania, zadamawiaja prywatna przestrzeń rekreacyjn i symbolicznie oznaczają osiedlową przestrzeń publiczną. Zaobserwowane działania najemców sprzyjają od- cated that he or she was a witness of the use of stimAs many as $60 \%$ of respondents declared that the were taking an active approach towards violations of the regulations in the public space of the housing estate, personally admonishing a person violatin the applicable rules $(40 \%$ of respondents), reporting violation to law enforcement $(15 \%)$ or managers (5\%). A direct reminder is addressed primarily to owners of doct rem in is adressed primarily to live outside the estate, which often leads to quarrels and argum th As a whion to this probuarrels f the repon cessibility of the pustic acted a limitation of the ac

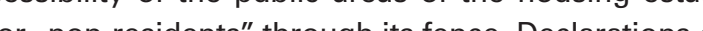
" general control over the behaviors of persons using the public space of the housing estate declared by the respondents indicate a high level of identification of residents with their place of residence, which is not disturbed by the lack of ownership of the premises. ewerrespondents who do not react to the observe behaviour inconsistent with the rules of order justifed this, among others, with the will to be neutral in difficult situation or low social harmfulness of thes acts. In the respondents' opinion, the estate is considered safe and very safe $(77.5 \%$ of respondents The tenants indicated the following dangerous areas: indoor car park and the neighborhood of the housing estate with a building with social premises. In these places, the tenants pointed to the destruction and robbing of vehicles, the danger of collision with vehicles and the annoying behavior of tenants of socia housing, ie throwing dangerous, sharp objects, food from windows and peeing. It is not without reaso that the tenants, facing the side of the car park and the building with social premises, more often isola ings.

\section{Summary}

TBS tenants operate in a system of strong restrictions resulting from the rules of the housekeeping regulations, failure to comply with which may be the basis or termination of the lease agreement. The statutory limitation of freedom in the rearranging of space did not eliminate the practices of its personalization ${ }^{8}$. The actions of tenants are basically in the rules of admissible changes specified in the regulations. Thing hat are acceptable and needed for tenants, such as the isolation of private recreational space, are commonly used. Territoriality ${ }^{9}$ is more expressive in the vicinity of an unfriendly public space penetrated by "non-residents". Tenants identify themselves with their place of residence, wonder about their private ecreation space and symbolically mark the neighborhood public space. Observed activities of tenants favor the feeling of identity and identification with the czuwaniu tożsamości i identyfikacji z miejscem a jednocześnie ograniczają ingerencje "ni mieszkańców przez demonstrację zasad wspólzycia społecznego, ograniczających swobodę dzlalan uznawanych na uciążliwe. Wprowadzane przez lokatorów zmiany wynikają z ich relacji budowanej z przestrzenią osiedla i rozwijającego się przywiązania do miejsca. Ksztaltowanie przestrze ni wynika też z potrzeby zapewnienta bezpieczenstwa $w$ świetle zidentyfikowanych zdarzen takich jak akty kradzieży, wandalizmu, uciążliwości akustycznej czy zaśmiecania otoczenia.

PRZYPISY

'art. 27 ust. 1 ustawy z 26.10.1995 r. o niektórych formach popierani 2 Osoby zgloszone do wspónego zamieszkania, w dniu objeccia lokalu, nis mei miesscowości a średni miesieczny dochód gospodarstwa dom nie może przekraczać określonego poziomu przecietnego wynagrodzenia
lart. 30 ust. 1 ust. 1 ustawy z 26.10 .1995 r. o niektórych formach popiera art. 28 ust. 1 ustawy z $26.10 .19955 \mathrm{r}$. o niektóngch r. porz. 1020 ze zem.) budownicwa mieszkaniowego (t.j. Dz.U. z 2018 r. poz. 1020 ze zm.)

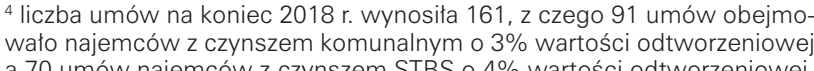

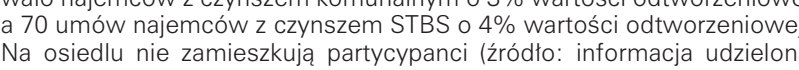
Na osiedlu nie zamieszk
przez STBS 231.10 .2018 :

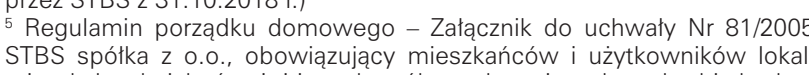

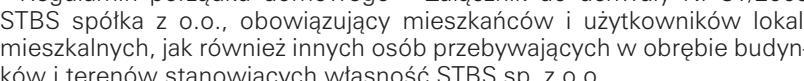
Wadamawianie prywatnej, przestrzeni rozumiane jako wyposazen

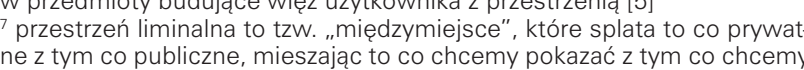
$n$ ne z tym co publiczne, mieszajac to co chcemy pokazác z tym co chcemy
ukryć, a wiec wykracza poza poiecie przestrzeni pótpublicznej [6]

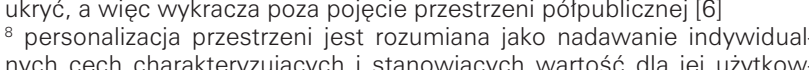
nych cech charakteryzujacych i stanowiących wartosć dla jej uìytkow
ników

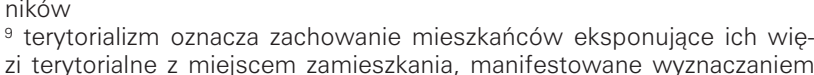
granic osiedlowych terytoriów i wzmacnianiem wasnych praw do nic

LITERATURA

1] Kowalewski M., Poczucie wasności mieszzania lokatorów towarzystw
budownictwa spotecznego, W: Ruch Prawniczy, Ekonomiczny i Socjologiczny, nr r 322009 s. s. $197-212$
21 Dzieciuchowicz

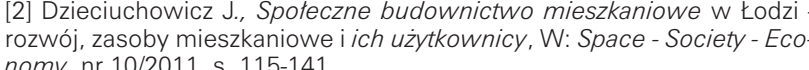
[1] Gawet D. Z badan' had rola spotecznego budownictwa czynnzzowego
W kstattowaniu srodowiska zamieszkania W Polsce, W: Architecturae et Artibus, nr 1 1/2009 s. 22-28

gicznych i spotecznych osiedli mieszkaniowych w. Teka Kom Arów. ekol- Ur

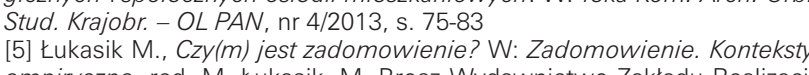

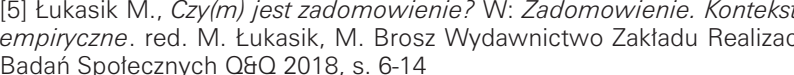

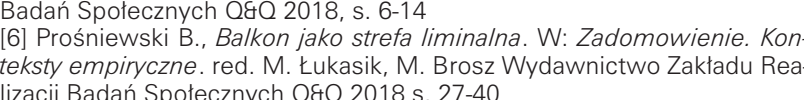

place and at the same time limit the interference of pron-residents by demonstrating the principles of social coexistence, limiting the freedom of actions considered to be burdensome. The changes introduced by the tenants result from their relationship built with the housing estate and developing attachment to the place. Space shaping also results from the need to ensure security in the light of identified

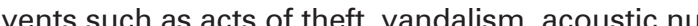
sance or littering the environment.

ENDNOTES

lart. 27 ust. 1 Act of October 26,1995 on certain forms of suppor-
ting housing construction (Dz.U. z 2018 r. poz. 1020 ze zm.) premises, cannot to be living together, on the day of taking up the and the average monthly income of the household cannot exceed
a certain level of average remuneration (art. 30 ust. 1 ust. 1 Act of a certain level of average remuneratitin art.
Octobor 26,1995 on certain forms of supporting housing construction (DZ.U. 22018 r. . p prz. 1020 ze zm).

art. 28 ust. 1 Act of October 26, 1995 on certain forms of suppoling housing construction (DZ.U. 22018 r. pozz. 1020 ze zm.. .
4 the number of contracts at the end of 2018 was 161 , of which 91
included tenants with municipal rent by $3 \%$ of r replacement value

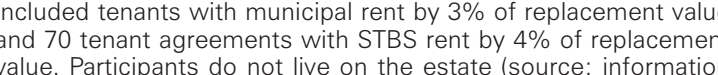
value. Participants do not live
provided by STBS z 31.10 .2018
Hous

Housekeeping regulations - Annex to the resolution $\mathrm{Nr} 81 / 2005$
STBS private Limited company, applicable to residents and users of residential premises, as well as other people staying within buil6 Possessing of the private space undertstood as an equipment in
objects that build a user's bond with space [5] "liminal space is called, inter-city" that intertwines what is privete with what is public, mixing what we want to show with what
we want to hide, and therefore goes beyond the concept of semi-
public space [6] -public space [6]
8 space personaliz istics and valueses to its us unders
territorialitity is the behavior of the inhabitants exposing their ties with territorial residence, residential maniniested deteterminination of beling space

BIBLIOGRAPHY

[1] Kowalewski M., Poczucie wtasności mieszkania lokatorów to-
warzystw budownictwa spotecznego, W: Ruch Prawniczy, Ekono-

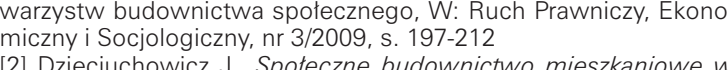

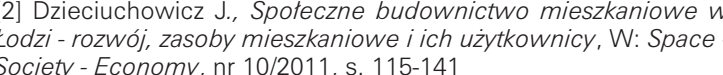

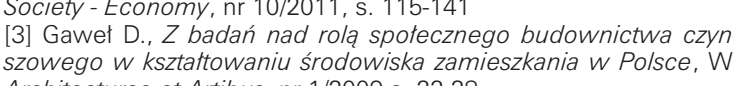
Architecturae et Artibus, nr 1/2009 s. $22-28$
[4] Trzaskowska E., Rola przedogródków w poprawie warunków ekologicznych i i solececznych o osiedli mieszkaniowych. W: Teka
Kom. Arch. Urb. Stud. Krajobr. - OL PAN, nr 4/2013, s. 75-83

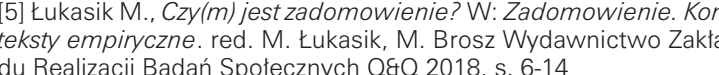

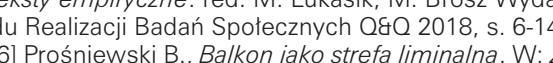
Konteksty empiniryczne, red. M. Lukkasik, M. Brosz Wydawnictwo Z 